\title{
Empirical Study of the Relationship between Ownership Structure and Firm Performance: Some Evidence of Listed Companies in Tehran Stock Exchange
}

\author{
Ghodratallah Talebnia \\ Assistant Prof. Islamic Azad University, Science and Research Branch, Tehran, Iran \\ Mahdi Salehi (Corresponding author) \\ Assistant Prof. Accounting and Management Department, Ferdowsi University of Mashhad, Iran \\ Tel: 98-91-2142-5323 E-mail:mahdi_salehi54@yahoo.com \\ Hashem Valipour \\ Faculty Member of Islamic Azad University, Firooz Abad Branch, Iran \\ Address: D.N 6, Zarganiha Alley, Mahdiyeh Area, Marvdasht City, Fars Province, Iran \\ Tel: 98-91-7308-6986Ｅ-mail: h.valipour@gmail.com \\ Shahram Shafiee \\ M.A Holder in Accounting, Islamic Azad University, Marvdasht Branch, Iran
}

\begin{abstract}
The study of effective factors seems essential since, the operation of profiting entities is very important in the decision of internal and external organization users. The effect of various factors on the assessment scale of operation was measured in different researches, e.g. the structure of ownership. In this study, the relationship between three kinds of various structures of ownership including the structure of shareholder's ownership and other firms and the structure of state ownership Q Tobin's operation scale of listed firms in TSE was considered. The effect of firm's age and size has considered as two control variables on the Q Tobin's operation scale. In this study, the statistical population is listed firms in Tehran Stock Exchange (TSE).

Theories are tested by multilateral Regression on the basis of $\mathrm{T}$ and $\mathrm{F}$ statistics. Finding shows that $\mathrm{Q}$ Tobin operation scale has significant relationship with two kinds of investment organization's ownership scale and other companies and state ownership, but it does not have significant relationship with minor shareholder's scale. Age and size of firms do not effect on Q Tobin operation scale as two control variables.
\end{abstract}

Keywords: Ownership structure, Minor shareholders, Investment organizations, State ownership, Q Tobin operation scale

\section{Introduction}

Efficient performance of entities earning profit effects on the process of current stock profit and on the application of investment to provide the future stock profit. Therefore, investor's especially common investors are interested in management efficiency. Present shareholders can change management in absence of efficient management and/or consider some rewards or advantages for efficient management. Potential shareholders try to assess the efficiency of management prior to investment or prior to assessment of profiting entities shares. In two above mentioned cases, efficiency scale provides a basis for making decision. The aim of entities earning profit efficiency assessment present in number one standards of financial statement: financial reports should provide information about profiting entities performance in financial period (Shabahang, 2004). Profiting entities performance effect on the decision of finance provider and creditors profiting entity, they consider profiting entity as a scale of making decision to granting debt and financial facilities to profiting entities. The study of effective factors seems essential, since the operation of profiting entity is important in the decision of internal and external organization users. The better performance of profiting entity caused the more investment of interested people and visa versa. One of the factors that its effect is confirmed on the profiting entities performance according to researches is firm ownership structure, while in internal researches the structure of ownership is studied from private or public perspective and/or the rate of share percent under the individual authority, but the kind of ownership structure was not studied individually, company or state approach. In this paper the relationship between ownership structure and firm is studied from different views.

\section{Research problem}

Investors, creditors and shareholders assess firm performance to make decisions. Performance assessing needs for some scales that called performance scale. One can define them in different ways as follows:

- The scale or assessment is kind of measuring that represents how to do and provide its doing motivation for us.

- One can make controllable indexes on the basis of scale (Zairi, 1994).

In different researches the effect of various factors were assessed on the scale of measuring; we can point to the 
ownership structure. In this paper, the effect of various ownership structures is measured on the scale of profiting entities performance includes Q Tobin. Some questions that were answered in this paper are as follows:

What is mean by ownership structure?

What kind of scales is used to measure the performance of profiting entities?

What is the effect of ownership structure on the scale of measuring performance?

Which kind of firm ownership structure will provide maximum Q Tobin?

Do the age and size of company effect on the performance scale of $Q$ Tobin?

After answering to this question will conclude that which kind of ownership is appropriate to better performance of TSE, for investors can sell or purchase their shares on the basis of firm performance.

\section{Review of literature}

The nature of relationship between ownership structure and firm's economic performance is originated from the authority literature of firm. From the viewpoint of firm's authority, profiting and firm performance are influenced by ownership structure (Barbosa and Laurie, 2002). Especially the ownership structure is kind of motivating means to decrease the cost of related agencies with the separation of ownership from the management. Theoretical literature of company's authority has suggested six different and important mechanisms to control the cost of agencies as follows:

1) The ownership structure (investment models in shares);

2) The structure of investment;

3) The structure of management board;

4) The reward of management;

5) The competition market of products; and

6) Dominant market (Kumar, 2006).

In this paper, the ownership structure is studied as an effective factor on the firm performance. The relationship between the ownership structure and firm performance has been the topic of various studies for the first time suggested by Berle and Means (1932). Berle and Means concluded in their research that with the increase of professionalism management, company use other management's profit rather than ownership profit that are company's shareholders. This wills effects on firm performance. Research center that studies relationship between ownership structure and firm performance is the agency theory that is used to explain the opposition of between the shareholders and decision makers (managers) within the company. According to Jensen and Meckling, The agency's cost of company is as a result of benefit opposition between ownerships and shareholders (Jensen and Meckling, 1976). In the record of related researches which are accompanied by the approach of agency cost, there are some mechanisms which are suggested to explain the relationship between firm performance and the ownership structure. Generally, theory of agency is used to analyze the relationship between management agents. But there is an increasing need to understand the opposition between the different levels of management, because some of ownerships have different techniques and tools to control the agency cost. It is possible that they have better information about management condition that leads to increase of firm performance. Recently some researchers have studied the role of company's authority in emerging economics with focus on the relationship between the ownership structure and firm performance. Clay (2002) studied the relationship between the organization's ownership and firm performance for US companies. He got following conclusions in his studies as follows:

1) One per cent increasing in the organization ownership leads to 2-6 per cent increase in the company's $Q$ Tobin as a performance measurement scale. Therefore, there is positive relationship between organization's ownership and firm performance.

2) The positive relationship between investment organizations of firm performance is more powerful in firms with high discretionary cash flows.

3) If organizations ownership and managers ownership considered as complementary, percentage increase in both of them lead to the increase of Q Tobin as a measurement scale of firm performance. Therefore, there is positive relationship between the percent of organization ownership and managers' ownership (while they considered as complementary to each other). In fact, in companies which have more internal employee's ownership, there is more effect in the percent of organization ownership on firm performance. Generally these findings support the idea that increase in the supervision motivations by managers' board and organization investors leads to increase the firm credit. Zuobawei and Zhang (2004) conducted a survey regarding the relationship between the ownership structure and firm performance in Chinese's private companies. At this reason he considered different kinds of ownership structures including state ownership, Organization's investing and external ownership as an independent variable and he studied its effect on the Q Tobin of 5284 companies Q Tobin as an assessment scale of ownership. The result of his survey shows that there is a negative relationship 
between the structure of state ownership and firm performance. The relationship between the structure of organization ownership and firm performance is also reported negatively significant, but in this paper there is a positive significant relationship between the external ownership structure and firm performance. In this paper, the mixed effect of state and institutional ownership structure is studied and reported that there is negative significant relationship between the ownership structure and firm performance. Karathanassis and Chrysanthopoulou (2004) studied the relationship between the ownership structure and benefit dividend policy in Athens stock exchange with using three benefit dividend policy including complete compatibility model, incomplete compatibility model and benefit process model for 55 stock company during 1996-1998. The findings of survey shows that there is positive significant relationship between the complete compatibility model and incomplete compatibility, while at the same model, there is a negative significant relationship between mangers ownership and firm performance. It seems that, these results are compatible with the theory of efficient supervision. In benefit process model, both ownership structure and benefit dividend policy have negative significant relationship. Jiang (2004) studied the relationship between the ownership structure and firm performance in China for listed companies in Hilon Jiang state in 1995-2000.

He classified the ownership structure variable on the basis of two concepts: on the basis of the ownership kind including estate, legal person's shares or legal organization's shares, local persons and on the basis of ownership centralization includes holding shares in 5 to 10 first ownership in high level. The scale of research performance assessment is ROE. He gets following results:

1) There is negative correlation between state shares and performance, while there is positive correlation between the shares of legal persons and performance

2) The effect of ownership centralization on firm performance for dominated companies by legal persons is stronger than dominated companies by state entities.

3) Various shareholders will have different effects on firm authority.

In Iran, Ghalibaf (2005) studied the effect of the ownership type on the firm performance (privatization experience in Iran). He assessed the effect of privatization on assigned firm performance to private and general sectors to study the improvement of firm performance before and after of assignment and to consider the effect of different types of ownership (private and general) on firm transferred on performance after assignment, in a way that it is be clear which kind of ownership (private or general) is better after the assignment period with the use of 18 firm statistical data(eight firms were assigned to privates sector and ten firms were assigned to general sector) which was assigned during 2000-2001, the three years performance of two types of companies was studied after and before of the assignment. After testing hypothesis it is cleared that first, there is no any significant first there is no any difference in firm performance which were assigned to private and general sectors after and before of the assignment. In other words after privatization, there is no any significant performance improvement in firm performance. Second, there isn't any significant relationship between the different types of private and/or general ownership after privatization and performance improvement.

\section{Significant of the study}

With regarding to increasing development of stock exchange in international level, the establishment of stock exchange in Iran and its noticeable development in recent years, more attention of investors, experts and clear-sighted persons to the cost of different firm shares in different times and finally the assessment of producing and commercial units management performance, research and study about the effective factors on commercial units performance have got high importance that its results is used in investment firms, stock exchange listed companies in stock exchange, experts, investors and analysts.

\section{Research objectives}

In this paper the following basic objectives are considered as follows:

1) Studying and identifying possible relationship between the firm performance and different ownership structure including minor shareholders, investment organizations and other companies and state ownership.

2) To consider the possible effect of company's age and size on the firm performance.

3) To represent a model to predict the firm performance with regarding to the research variables.

4) To consider the condition different firm performance in Iran and their different performance reasons.

5) To provide information for investors, managers and analysts about effective factors on firm performance to making economic decisions.

\subsection{Research questions}

1) Is there any significant relationship between the type of minor shareholders ownership and listed companies Q Tobin performance scale in TSE?

2) Is there any significant relationship between the structure type of investment organization's ownership and listed companies Q Tobin performance scale in TSE? 
3) Is there any significant relationship between the structure of state ownership and listed companies Q Tobin performance scale in TSE?

4) Do the age of company effect on Q Tobin performance scale?

5) Do the size of company effect on Q Tobin performance scale?

\section{Research hypotheses}

With regard to mentioned matters about the research problem, aims and studying in literature and theoretical basis, there are possible relationship between the different ownership structure and the firm performance and firm age and size effect on the firm performance. Therefore, with regard to the available facilities, three different kinds of ownership structures were selected and their possible relationship with the firm performance with regarding to the possible effect of company's age and size on firm performance was expressed in the form of following hypotheses:

The first hypothesis: there is significant relationship between the type of minor shareholder's ownership and listed companies Q Tobin performance scale in TSE.

The second hypothesis: There is significant relationship between the structure type of investment organization's ownership and listed companies Q Tobin performance scale in TSE.

The third hypothesis: there is significant relationship between the structure of state ownership and listed companies Q Tobin performance scale in TSE.

The fourth hypothesis: the age of company effects on Q Tobin performance scale. The fifth hypothesis: the size of company effects on Q Tobin performance scale.

\subsection{Research variables}

Research variables are including independent variable of the ownership structure in three different levels including minor shareholders ownership structure and investor organization ownership structure and other companies, the structure of state ownership and control variable including company's age and size Q Tobin dependent variable that calculated as follows:

- The Ownership structure: it means that some percent of firm ownership which is in the authority of different investor groups.

- Minor shareholders: that percent of firm ownership which is in the authority of minor shareholders. Minor shareholders are the individual investors who have only less amount of investment one but generally, they allocated high amount of major firm investment to themselves.

- Investment organizations and other companies: That percent of firm ownership which is in the authority of investment organizations and other companies.

- State ownership: That percent of firm ownership which is in the authority of state or state organization. Control variables are as follows:

1) Company's age: The number of years from company's establishment up to the research period.

2) Size of company: Company's total sale logarithm during the research period.

3)Simple Q Tobin: The value of company's assets market ratio and the value of debts in the ratio of company's assets.

\section{Research methodology}

In fact, statistics population is including all elements that apply in modified research and we would like to infer them. In other words the population is all real or supposed members that all research findings are generalized to them. Therefore, the definition of given population is essential to careful sampling. The limitation of each research populations was cleared by its definition and the definition of population is stated in terms of research question importance and combining features of population researching topic (Homan, 2005). The statistical population of this survey is those firms which are listed in TSE until and they keep their situation in stock exchange the research. The following features are considered to determine an ideal statistical population:

A. Firms should be listed in TSE up to the end of 2008.

B. The financial date of firms should be finished at the last month of each year.

C. The firms shouldn't modify their financial year during the periods.

D. The firms shouldn't suspend their works during the periods.

E. The firms should have positive profit during the periods.

If they have negative profit or zero profit they will be removed from statistical population. At first to determine the sample variance was estimated by using primary sample and then major sample determined by sample formula. Sample population was classified by random sampling.

Research on the basis of their goals divided into several groups that every of them use different methods to get 
result. Some surveys are done to study the relationship between several factors or variables. Usually, in this cases statistics tests are used (e.g., Regression methods, correlation analysis method etc) which are related to the correlation concept. Noticeable points in such this research are all data which are used to different factors should be related to each other. This investigation is descriptive applicable type which its aim is to be aware of ownership structure effect on the firm performance. The model used investigation is:

Firm performance $=$

$\mathrm{B}_{0}+\mathrm{B}_{1}\left(\% \mathrm{own}_{1}\right)+\mathrm{B}_{2}\left(\% \mathrm{own}_{2}\right)+\mathrm{B}_{3}\left(\% \mathrm{own}_{3}\right)+\mathrm{c}_{10}(\mathrm{AGE})+\mathrm{c}_{2}(\mathrm{SIZE})$

Firm performance $=$

$\% \mathrm{own}_{1}=$ total share percent under insignificant shareholders authority.

$\% \mathrm{own}_{2}=$ total share percent under investor organizations and other companies authority.

$\% \mathrm{own}_{3=}$ total share percent under government or government organizations authority.

Age= company's age (number of year from establishing of company establishment to research period).

Size $=$ company's size (total logarithm of company's sell in research period)

All necessary data of independent variable, dependent and control variable are extracted from financial reports of management board and firm bill during 2006-2008. In this paper, library method was used for collecting research literature.

\subsection{Data analysis}

All collected data analyzed by SPSS software. Data Analysis is including Multi-regression model and conducted on the basis of $\mathrm{T}$ and $\mathrm{F}$ statistics in a 5 per cent significant level. In this research, the $\mathrm{H} 1$ and $\mathrm{H} 0$ hypotheses are defined statistics with regard to supposed model as follows:

$\mathrm{H} 0: \mathrm{B} 1=\mathrm{B} 2=\mathrm{B} 3 \ldots \ldots=\mathrm{BK}=0$

Opposite $\quad \mathrm{H}_{1=} \mathrm{H}_{0}$

If Sig. $<5 \%$ or/and $\mathrm{F}>\mathrm{F}\left(\mathrm{d}_{\mathrm{f} 1}, \mathrm{df} 2\right) \alpha$, then $\mathrm{H} 0$ rejected, otherwise $\mathrm{H}_{0}$ confirmed (the confirming of $\mathrm{H} 0$ means lack of significant relationship between dependent and independent variable).

\section{Results and analyses of hypotheses testing}

The Results of statistical tests are as follows:

step1: at first, the descriptive statistic research variables are provided as following table:

Insert Table 1

With regard to Table 1, the lack of significant relationship between the firm performance and other variables are studied and expressed statistically as significant relationship between them as follows:

$\mathrm{H}_{0}: \mathrm{B}_{1}=\mathrm{B}_{2}=\mathrm{B}_{3}=\mathrm{C}_{1}=\mathrm{C}_{2}=0 \quad$ Opposite $\quad: \mathrm{H} 1=\mathrm{H}_{0}$

$\mathrm{H}_{0}$ hypothesis represents that there is no any significant relationship between firm performance and other Models of variables.

Step 2: the ANOVA table are provided as follows:

Insert Table 2

Since $\mathrm{p}$-value is $5 \%>25 \%$ thus H0 hypothesis is rejected. It means that there is a $5 \%$ significant relationship between the firm performance and other Models of variables.

Since it isn't clear which sample variables has significant relationship with performance so the index of Regression model is provided as follows:

Insert Table 3.

By using retrospective method and with regard to Table 3 it is cleared that the ownership of minor shareholders ownership, state ownership, size and age of company has more than $5 \%$ p-value that shows their lack of effects. So, the performance has significant relationship just with the ownership variable of investment organizations and other company's variables. In this step, the ownership of variable minor shareholders which have $5 \% \mathrm{P}$-value sizes and age of company more than state ownership is rejected.

Rejecting non-effective variables on the basis of retrospective methods and providing of ANOVA tables and Regression model index are continued for three steps up to the last step, ANOVA tables and Regression model is provided as follows:

Insert Table 4

Step3: ANOVA is provided again from pervious tables to consider the H0 hypothesis and with rejecting the company's size and age variables. With regard to table 4 since, p-value is $5 \%>0.002$ thus $\mathrm{H} 0$ hypothesis is rejected. It means that there are $5 \%$ significant relationships between the firm performance and other model of variables. Since it is not clear which models of resting variables have significant relationship with performance, 
so the index of Regression model is provided as follows:

In this model we consider that in table 5 there are two kind of structure investment organization ownership and other companies and the state structure of ownership.

Insert Table 5

Both of them have less then 5 per cent p-value, it means that there are significant relationship between performance and two types of ownership structure. The last model of research regarding to the amount of $\mathrm{R} 2=172$ per cent and $\mathrm{R}=145$ and above mentioned tables are as follows:

Firm performance $=6.313-6.944$ (own2)-3.34(own3)

According to the mentioned levels, the results of research are expressed as follows:

One can say that there are significant relationship between the scale performance of Q Tobin and investment organization ownership structure and other companies and state ownership structure. As a result we consider H0 in second and third hypothesis which indicates that there is no any significant relationship between the scale performance of Q Tobin and two ownership structures (that is rejected). But we consider H0 in first hypothesis which indicates that there is no any significant relationship between the scale performance of Q Tobin and two ownership structures that is not rejected. The age and size of company as two control variables don't effect on firm performance. Therefore, we consider H0 in fourth and fifth hypothesis which indicates that two control variables on the performance scale of Q Tobin that is not rejected.

\section{Results and Recommendations}

Results indicates that there are significant relationship between the scale performance of Q Tobin and the ownership structure of investment organization and the structure of state ownership but there is no any are significant relationship with the ownership structure of minor shareholders. The Age and size of company as two control variables do not effect on the Q Tobin performance scale. The significant relationship between Q Tobin performance scale and investment institutional ownership structure and other companies are corresponded to the findings of Clay (2002) in US and Karathanassis and Chrysanthopoulou (2004) in Zuobawei (2004) in China.

Recommendations for future research

According to the results of this survey, we recommend that this investigation is reconsidered in future years. The quality of research is increased by producing ability of last results of research and managing design and different models and this matter cause to increase the external validity of research. At this reason the following topics can be studied:

1) To survey the relationship between the investment structure and firm performance.

2) To survey the relationship between the structure of managers board and firm performance.

3) To survey the relationship between the management rewards and firm performance.

4) To survey the relationship between the competitive market of products and firm performance.

5) To survey the relationship between the dominant market and firm performance.

6) To survey the relationship between the corporate governance and firm performance.

\section{References}

Barbosa, Natalia, and Helen Louri. (2002). On The Determinants of Multinationals' Ownership Pref-erences: Evidence from Greece and Portugal, International Journal of Industrial Economics, Vol. 20, pp. $493-515$.

Berle, Adolf A., and Gardiner C. Means. (1932). The Modern Corporation and Private Property, (Lar-court,Brace \& World Inc. New York Republished: 1968)).

Clay Darin G. (2002). Institutional Ownership and Firm Value, Working Paper, University of Southern California, Marshall School of Business.

Ghalibafasl, H. and Rangbardargah, F. (2004). Study on the Type of Ownership Effect on Firm Performance, Iranian Financial Research, 12, pp.117-132.

Homan H. (2004). Statistic on Behavioral Science, Parsa Publication, Iran.

Jensen, Michael C., and Meckling, William H. (1976). Theory of the Firm: Managerial Behavior, Agency Costs and Ownership Structure, The Journal of Financial Economics, Vol. 3, pp. 305-360.

Jiang Ping. (2004). The Relationship between Ownership Structure and Firm Performance: An Empirical Analysis over Heilong jiang Listed Companies, Working Paper, Department of Economy and Management Heilong jiang University.

Karathanassis, G.Aand Chrysanthopoulou. E.ch. (2004). The Relationship between Ownership Structure and Corporate Dividend policy -Evidence from the Athens Stock Exchange, Working Paper, Department of Business Administration, Athens University of Economics and Business, Greece.

kumar Jayesh. (2006). Agency Theory and Firm Value, Working Paper, Indira Gandhi Institute of Development 
Research.

Shabahang, R. (2004). Accounting Theory, Iranian Accounting Organization Publisher, Iran.

Zairi, M. (1994). Measuring Performance for Business Results, Chapman \& Hall, London, UK.

Zuobao wei, Feixue xie, and Shaorong Zhang. (2004). Ownership Structure and Firm Value in china's Privatized Firms:1991-2001. Working Paper, Department of Economics and Finance University of Texas at EL Paso.

Table 1. The descriptive statistic of research variables

\begin{tabular}{|l|c|c|}
\hline Name of Variable & Average & Variance \\
\hline Q TOBIN & 2.8204 & 2.60268 \\
\hline the ownership of major shareholders & 0.2356 & 0.20226 \\
\hline the ownership of other companies and organization's & 0.3998 & 0.19962 \\
\hline state ownership & 0.2145 & 0.23269 \\
\hline Size of company & 5.2440 & 0.49789 \\
\hline Age of company & 31.8286 & 10.7440 \\
\hline
\end{tabular}

Table 2. ANOVA table

\begin{tabular}{|l|l|l|l|l|l|}
\hline $\begin{array}{l}\text { The resources of } \\
\text { changes }\end{array}$ & $\begin{array}{c}\text { Total } \\
\text { square }\end{array}$ & $\begin{array}{c}\text { Degree of } \\
\text { freedom }\end{array}$ & $\begin{array}{c}\text { Square } \\
\text { average }\end{array}$ & $\begin{array}{l}\text { Fisher } \\
\text { Test }\end{array}$ & $\begin{array}{l}\text { P-value } \\
\text { Sig. }\end{array}$ \\
\hline regression & 83.186 & 5 & 16.637 & 2.771 & 0.025 \\
\hline Total & 384.216 & 64 & 6.003 & & \\
\hline Rest & 467.402 & 69 & & & \\
\hline
\end{tabular}

Table 3. the index of Regression model

\begin{tabular}{|l|l|l|l|}
\hline Name of variable & $\begin{array}{l}\text { Mmm } \\
\text { Model index }\end{array}$ & T- Test & P-value Sig. \\
\hline Invariable & 8.267 & 2.469 & 0.016 \\
\hline Minor shareholders Own & 0.295 & 0.170 & 0.866 \\
\hline Other companies invested & -6.656 & -3.060 & 0.003 \\
\hline State ownership & -2.889 & -1.512 & 0.136 \\
\hline Size of firm & -0.385 & -0.611 & 0.543 \\
\hline Age of firm & -0.007 & -0.230 & 0.819 \\
\hline
\end{tabular}

Table 4. ANOVA table

\begin{tabular}{|l|l|l|l|l|l|}
\hline $\begin{array}{c}\text { The resources } \\
\text { of changes }\end{array}$ & $\begin{array}{c}\text { Total } \\
\text { square }\end{array}$ & $\begin{array}{c}\text { Degree of } \\
\text { freedom }\end{array}$ & $\begin{array}{c}\text { Square } \\
\text { average }\end{array}$ & $\begin{array}{l}\text { Fisher } \\
\text { Test }\end{array}$ & $\begin{array}{c}\text { P-value } \\
\text { Sig. }\end{array}$ \\
\hline regression & 80.584 & 2 & 40.292 & 6.979 & 0.002 \\
\hline Total & 386.818 & 67 & 5.773 & & \\
\hline Rest & 467.402 & 69 & & & \\
\hline
\end{tabular}

Table 5. Index of Regression model

\begin{tabular}{|c|c|c|c|c|}
\hline Name of variable & Index model & T-test & P-value & Results \\
\hline Invariable & 6.313 & 6.075 & 0.000 & Significant \\
\hline $\begin{array}{c}\text { Other companies } \\
\text { invested }\end{array}$ & -6.944 & -3.721 & 0.000 & Significant \\
\hline State ownership & -3.340 & -2.086 & 0.041 & Significant \\
\hline
\end{tabular}

